\title{
Bioelectricity Production from Microalgae-Microbial Fuel Cell Technology (MMFC)
}

\author{
Carlito da Costa and Hadiyanto ${ }^{*}$ \\ Chemical Engineering Department, Faculty of Engineering, Diponegoro University Jl. Prof. Soedarto, Tembalang, Semarang 50239, \\ tlp/fax : (024)7460058
}

\begin{abstract}
Microbial fuel cell is an ecological innovative technology producing bioelectricity by utilizing microbes activity. Substituent energy is produced by changing the chemical energy to electrical energy through the catalytic reaction of microorganism. The research aims to find out the potency of bioelectricity produced by microalgae microbial fuel cell technology by utilizing the combination of tapioca wastewater and microalgae cultivation. This research is conducted through the ingredients preparation stage microalgae culture, wastewater characterization, membrane and graphite activation, and the providing of other supporting equipment. The next stage is the MMFC arrangement, while the last one is bioelectricity measurement. The result of optimal bioelectricity production on the comparison of electrode $2: 2$, the power density is $44,33 \mathrm{~mW} / \mathrm{m}^{2}$ on day 6 , meanwhile, on that of $1: 1,20,18 \mathrm{~mW} / \mathrm{m}^{2}$ power density on day 1 is obtained. It shows that bioelectricity can be produced from the combination of tapioca wastewater and microalgae culture through the microalgae- microbial fuel cell (MMFC) technology. This research is expected to be a reference for the next research particularly the one that observes the utilizing of microalgae as the part of new and renewable energy sources.
\end{abstract}

\section{Introduction}

Along with the times, our needs of energy become the priority in mobilizing our daily activities. Energy becomes the important aspect of any activities utilizing the facilities and infrastructures as the support of continuity and success. The economic wheel is driven by energy. Energy that is available and dominant nowadays is fossil fuel energy. The creation of fossil energy takes a really long time and will be exhausted in a certain time, and it is not considered eco-friendly[1].

The use of fossil energy appears some problems, namely the reducing available volume, the difficulty of finding new reserve, the unstable price, and the pollution emerging from the fossil fuel usage[2].

Problems emerged by the use of fossil energy trigger the development of technology which can produce ecofriendly, easy to get, and renewable energy [3].

One energy from aquatic herbs which is potential to be developed, eco-friendly, and competitive is microalgae. The potency of microalgae development is important in the future since microalgae have preeminence as food material, supplement, biodiesel, and bioethanol. It can also be utilized as the electricity producer.

Instead of microalgae cultivation, wastewater produced from tapioca production process, contains starch and hydrosianate acid ( $\mathrm{HCN})$, can be elaborated into cyanide, nitrogen, phosphorus, and other organic compounds. If the tapioca wastewater is directly discarded without any treatment, it will endanger the surroundings. [4].

Nowadays, MFC is based on supporting theories, such as utilizing wastewater [5], utilizing waste of alcoholic beverage manufacture [6], and utilizing domestic wastewater [7]. Based on the reports, MMFC technology utilizing microalgae and wastewater is potential to be developed since those two ingredients are easy to find. Both microalgae and wastewater contains nutrition such as carbohydrate, glucose, and fat which are potential to be utilized. Nutrition in the wastewater is a food source for the growth of bacteria while oxygen is produced by microalgae through photosynthesis[8]. The purpose of this research purpose was to investigate the potency of bioelectricity production from microalgaemicrobial fuel cell. The evaluated parameters are the COD concentration of tapioca wastewater and the microalgae's growth rate.

\subsection{Microalgae}

One potential alternative energy source which is renewable and eco-friendly is microalgae [9]. Light and water are used by microalgae as the energy source in

Corresponding author: hadiyanto@,live.undip.ac.id 
conducting carbon dioxide metabolism to produce biomass as explained on this photosynthesis reaction:

$$
\mathrm{CO}_{2}+\mathrm{H}_{2} \mathrm{O}+\text { lights } \rightarrow \quad \mathrm{CH}_{2} \mathrm{O}+\mathrm{O}_{2}
$$

Oxygen is the side product which is used to form water in the cathode while the transfer ions of electrons and protons of hydrogen atoms occurs. Oxygen is produced by algae through photosynthesis using solar energy while the nutrient and bicarbonate metabolism process is produced by microorganism [10]. The excellence of Microbial Fuel Cell by utilizing microalgae cultivation is because it is efficient and ecofriendly. It naturally changes chemical energy into electricity. It also plays an important role in overcoming air pollution [11].

\subsection{Tapioca Wastewater}

According to [12], tapioca industry can produce $4-12$ $\mathrm{m}^{3}$ of wastewater for each ton of tapioca flour. It contains $4.5-5.0$ of $\mathrm{pH}, 10.000-15.000 \mathrm{mg} / \mathrm{L}$ of COD with $19-28 \mathrm{mg} / \mathrm{L}$ cyanide compound. The cyanide compound in tapioca wastewater can kill methanogen bacteria and reduce the content of methane. Smith et al, [13] stated the contents of tapioca wastewater are $300-$ $7500 \mathrm{mg} / \mathrm{L}$ of BOD, $3100-20000 \mathrm{mg} / \mathrm{L}$ of COD, and $1500-8500 \mathrm{mg} / \mathrm{L}$ of TSS. Suspended organic compounds in the tapioca wastewater - protein, fat, and carbohydrate which is easily decomposed - can obstruct the respiratory system and inorganic compounds such as cyanide and ammonia $\left(\mathrm{NH}_{3}\right)$. It also endangers the marine biota [14].

Organic ingredients consumed by microorganism become new biomass cell and organic substance which produce energy from oxidation reaction and is utilized for metabolism process [15].

\section{Microalgae-Microbial Fuel Cell (MMFC) Technology}

One way to reduce the pollution caused by tapioca wastewater is Microbial Fuel Cell (MFC). MFC is a mean used to oxidize organic and inorganic ingredients using bacterial activities [16].

Microalgae-Microbial Fuel Cell (MMFC) technology utilizes the result of microalgae photosynthesis as an oxygen in the cathode [17] with the tapioca wastewater as the anode to produce bioelectricity. According to [18], by using dual chamber with the electrolyte of proton exchange membrane (PEM), MFC produces 61,62 $\mathrm{W} / \mathrm{m}^{2}, 0,57 \mathrm{~V}$ and $0,12 \mathrm{~A}$ with tapioca wastewater as the anode.

Electrons moving in anode chamber is consumed by the growing microbe cells, while, in cathode chamber, microalgae convert $\mathrm{CO}_{2}$ into oxygen and biomass via photosynthesis [19]. Oxidized mediator is transformed to the medium by cell. The cycle is repeated. Mediator is reduced by electrons in catholyte [20]. During illumination, biochemical reaction in the anode and cathode is respectively formulated in [21].

$\mathrm{C}_{6} \mathrm{H}_{12} \mathrm{O}_{6}+6 \mathrm{H}_{2} \mathrm{O} \stackrel{\text { oxidation }}{\longrightarrow} 6 \mathrm{CO}_{2}+24 \mathrm{H}^{+}+24 e^{-}$

$6 \mathrm{CO}_{2}+12 \mathrm{H}^{+}+12 e^{-} \stackrel{\text { lights }}{\longrightarrow} \mathrm{C}_{6} \mathrm{H}_{12} \mathrm{O}_{6}+3 \mathrm{O}_{2}$

\section{Materials and Methods}

\subsection{Materials}

The material used as the catholyte is microalgae species spirulina platensis. It is obtained from PT. Neoalgae, Sukoharjo. Meanwhile, tapioca wastewater as the anolyte is obtained from Kedungsari Village RT/RW 01/01, Tayu, Pati Regency, Central Java. The other materials used are nafion 117 membrane with diameter 0.5 inch, while the electrode is a graphite bar [22] with $10 \mathrm{~cm}$ length and $7 \mathrm{~mm}$ diameter, and 1 meter of copper wire.

\subsection{Methods}

The research is conducted in the C-BIORE integrated laboratory of Diponegoro University, Semarang. The mechanism of electron transfer from the bacteria to the anode is through the mediator produced by the bacteria [23].

The power density value was calculated based on the influence of the wide of electrode surface and the membrane circle.

The wide of the electrode surface and the membrane circle was calculated by following equation[24]:

$P=V x I$

where $P$ is power density (W), I is Current (A), and V is Voltage (V).

Power density can be influenced by the wide of electrode surface and membrane, so the equation is:

$$
P=\frac{V \times t}{A_{\text {Total }}}
$$

\subsection{Experiment procedures}

Spirulina platensis is diluted (based on cultivation standard), 3 liters are taken and tested - absorbance and wavelength test. The next stage is the tapioca wastewater characterization - the test of sample COD content, the absorbance and the wavelength test of bacterial cell.

The research used four reactors or two pairs of reactor. Each of them contains 3 liters of tapioca wastewater and 3 liters of cultivated microalgae. Each pair is connected by tube with membrane as the media of 
ion proton transfer and as the separator between anolyte and catholyte. Each reactor respectively filled by graphite electrode 1:1 and 2:2 bars. Both reactors filled by microalgae culture is aerated and 24-hour illuminated for 8 days. The illumination used 15-watt lamps with 20 $\mathrm{cm}$ distance. After all tools and materials are set, measure bioelectricity and test the sample every 24 hour. Bioelectricity observation is conducted every 6 hour for 15 minute for each observation, or the measurement result has showed the constant value as the optimum value. The analysis conducted by spectrophotometry is measuring wastewater COD concentration, the density of wastewater bacterial cell and microalgae cell [25].

\subsection{MMFC equipments}

Tools that are used in MMFC technology are based on modified [26]. MMFC tools design is based on the microbial fuel cell research, namely electrode and membrane usage [27] type of substrate [18], the reactor design [7].

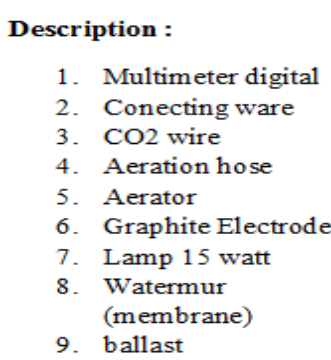

9. ballast

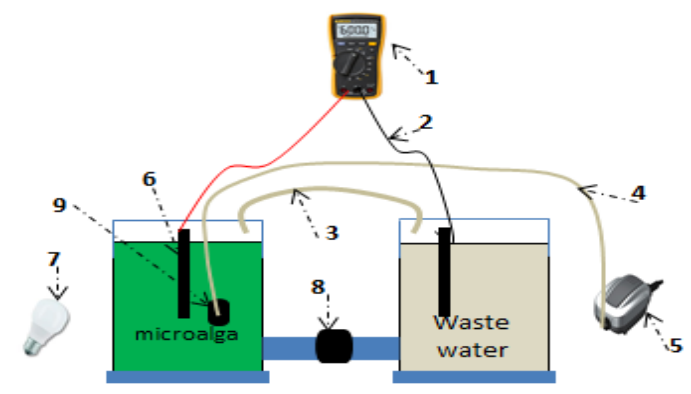

Fig. 1 MMFC series

\section{Result and Discussion}

Bioelectricity produced from dual chamber on the microalgae-microbial fuel cell (MMFC) technology can be shown by the following:

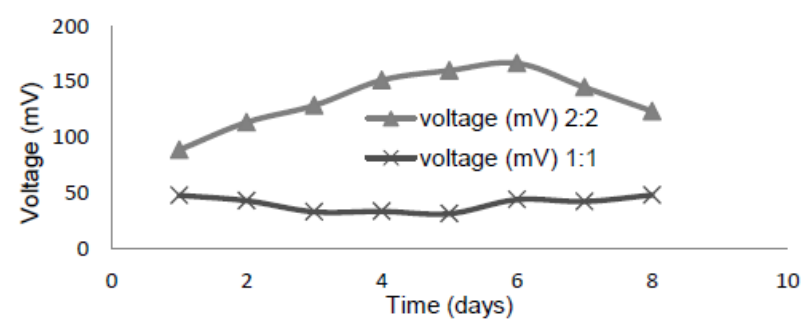

Fig. 2. Bioelectricity Production in Time

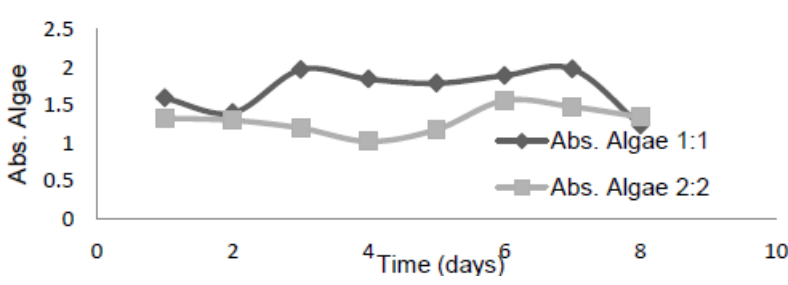

Fig. 3. The Effect of Microalgae Growth in Bioelectricity Production

The results shown in the graph above is the voltage obtained on the difference in the number of electrodes where the use of the number of electrode 2: 2 increased the value of higher voltage that is on day 6 of 166,537 $\mathrm{mV}$ with the absorbance value of microalgae cell growth of 1.558 on the same day. While the optimum value achieved on the use of 1: 1 electrode amounted to
48.15 on day 8 with the absorbance value of microalgae cell growth of 1.235.

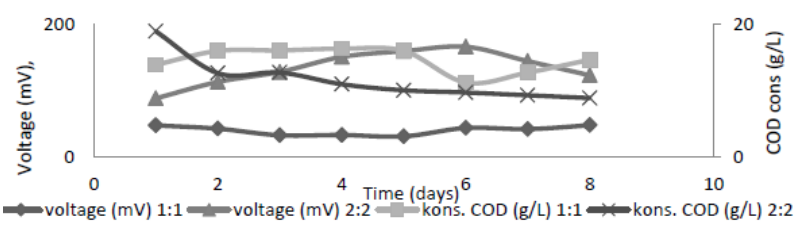

Fig. 4. COD and Voltage Change During MMFC Operation

Data obtained from sample analysis showed that the COD value of tapioca wastewater is significantly decreased $(9,7573 \mathrm{~g} / \mathrm{L})$ with microalgae absorbance value of 1.558. Sample analysis result of the wastewater optical density showed the deccreasing absorbance value $(0,149)$ on the same day using 1:1 electrodes.

It should be noted that bioelectricity obtained from MMFC technology is small if compared to ([11],[22]), They respectively produce $1926 / 21.4 \mathrm{~mW} / \mathrm{m}^{2}$ $\left(8.67 / 0.10 \mathrm{~W} / \mathrm{m}^{3}\right)$ and $13.5 \mathrm{~mW} / \mathrm{m}^{-2}$ power density. It is due to the high carbohydrate content in the tapioca wastewater, so it makes the hydrolysis process slower.

\section{Conclusion}

It can be inferred that the obtained bioelectricity has not showed the significant result yet. It is due to some factors, namely:

1. The tapioca wastewater is only 2 days old since the production time until it is used in the MMFC technology, so the bacteria growth is obstructed by the high concentration of cyanide The tapioca wastewater was not characterized first. It is shown by its high COD concentration $(16,5304$ $\mathrm{g} / \mathrm{L}$ ) so it obstructed the growth of bacteria. 
After conducting this research, bioelectricity with maximum power density occurred on day $6(44,33$ $\mathrm{mW} / \mathrm{m}^{2}$ ), with $9,7573 \mathrm{gL}^{-1}$ COD concentration, 2.17 bacteria cell absorbance, and 1.558 microalgae cell absorbance on 2:2 electrodes and 0.5-inch diameter of pipes.

\section{References}

1. V. Patil, K.Q.Tran, and H.R.Giselrod, Int. J. Mol. Sci., 9, 1158-1195 (2008)

2. Ditjenbun. Jakarta : Diretorat Jenderal Perkebunan, Departemen Pertanian, (2006).

3. E. Metcalf., 3rd Edition. Singapore : McGraw Hill Inc., (1991).

4. Mukminin , Wygnyanto and N. Hidayat., J. Teknologi Pertanian Brawijaya, 4(2): 91-107. (2003)

5. Hyonsoo, I.Moon, I. S. Chang and H.K. Byung., Science Direct. Biores. Technol., 97, 621-627. (2006)

6. Y. Feng., X. Wang, B.E Logan and H. Lee., Springer- Verlag. Appl Microbiol Biotechnol, 78,873-880 (2008)

7. H. Liu, and B.E. Logan, Environ. Sci. Technol, pp. 38(14), 4040-4046. (2004)

8. H. Hadiyanto, and M.M.A. Nur., World Appl. Sci. J., 5, 959-967. (2014)

9. Y. M. Li, B. W. H. Wang and C. Wu, and Q Lan., Appl. Microbial Biotechnol, pp. 81, 629-636. (2008)

10. P. Kruzic and J.F. Kreissl., Water Environ. Res., 81(10):1346-1360. (2009)

11. Y. feng, N. Cui, et al., et al., Energy, pp. 79, 674680. (2013)

12. Eva, Oktarina. (2014).

13. Sumestri, Sri and Alaerts. Surabaya Utama : Usaha Nasional, (1984).

14. F.P. Riyanti, Lukitowati and T. Afrilianna., J. Penelitian Sains, 13(3):34-39. (2010)

15. D.A. Oktavia, et al., Agrointek, 6(2):65-71. ( 2012)

16. H.J. Kim, Enzyme and Microbial Technology, pp. 30, 145-152. (2002)

17. J. Lobato, Applied Energy, 110, 220-226. (2013)

18. F.N. Cahyani., IPCBEE, 6, 218-220. Singapore: IACSIT Press. (2011)

19. D.Parlevliet and N.R. Moheimani., Aqua. Biosys., 10,14. (2014)

20. E.E. Powell and G.A. Hill., Chem. Eng. Res. Des., 87(9): 1340-1348. (2009)

21. M. Zhou., J. Power Sources, 216-219. (2012a,b),

22. G. Araceli, D. Campo, Journal of Power Sources, 242, 638-645. (2013)

23. K. Rabaey and W. Verstraete., J. Biotechnol, 23, 291- 298. (2005)
24. Y.O. Momoh and B. Naeyor., J. Biochem Tech, pp. 2(4): 216-220. (2010) APHA. 21 st Edition. Washington DC : APHA,AWWA, (2005).

25. B.E. Logan, : A John Wiley \& Sons Inc, (2008).

26. S. Cheng, H. Liu and B.E. Logan ., J. Environ Sci. Technol., 40:364-369. (2006b) 